Research Article

\title{
Photocatalytic Degradation of Polyethylene Microplastics and Disinfection of $E$. coli in Water over Fe- and Ag-Modified $\mathrm{TiO}_{2}$ Nanotubes
}

\author{
Yuwendi Yuwendi, Muhammad Ibadurrohman, Setiadi Setiadi, Slamet Slamet* \\ Department of Chemical Engineering, Faculty of Engineering, Universitas Indonesia, Depok 16424, \\ Indonesia.
}

Received: $13^{\text {th }}$ January 2022; Revised: 23rd February 2022; Accepted: $23^{\text {rd }}$ February 2022 Available online: $2^{\text {nd }}$ March 2022; Published regularly: June 2022

\section{Abstract}

In this study, $\mathrm{Fe}$ - and $\mathrm{Ag}$-modified $\mathrm{TiO}_{2}$ nanotubes were synthesized via an anodization method as photocatalysts for degradation of polyethylene microplastics and disinfection of Escherichia coli (E. coli). The anodization voltage, as well as the $\mathrm{Fe}^{3+}$ or $\mathrm{Ag}^{+}$concentrations on $\mathrm{TiO}_{2}$ nanotubes were evaluated and correlated to their corresponding photocatalytic properties. $\mathrm{TiO}_{2}$ nanotubes were firstly synthesized by anodization of $\mathrm{Ti}$ plates in a glycerol-based electrolyte, followed by incorporation of either $\mathrm{Fe}$ or $\mathrm{Ag}$ via a Successive Ionic Layer Adsorption and Reaction (SILAR) method with $\mathrm{Fe}\left(\mathrm{NO}_{3}\right)_{3}$ and $\mathrm{AgNO}_{3}$ as Fe and $\mathrm{Ag}$ precursors, respectively. UV-Vis DRS shows that the addition of $\mathrm{Fe}$ or $\mathrm{Ag}$ on $\mathrm{TiO}_{2}$ nanotubes causes a redshift in the absorption spectra. The X-ray diffractograms indicate that, in the case of Fe-modified samples, $\mathrm{Fe}^{3+}$ was successfully incorporated into $\mathrm{TiO}_{2}$ lattice, while Ag scatters around the surface of the tubes as $\mathrm{Ag}$ and $\mathrm{Ag}_{2} \mathrm{O}$ nanoparticles. A microplastic degradation test was carried out for 90 mins inside a photoreactor with UVC illumination. $\mathrm{TiO}_{2}$ nanotubes that are anodized with a voltage of $30 \mathrm{~V}$ exhibit the best degradation results with $17.33 \%$ microplastic weight loss in 90 mins. Among the modified $\mathrm{TiO}_{2}$ nanotubes, $0.03 \mathrm{M} \mathrm{Ag}-\mathrm{TiO}_{2}$ was the only one that surpassed the unmodified $\mathrm{TiO}_{2}$ in terms of microplastic degradation in the water, offering up to $18 \%$ microplastic weight loss in $90 \mathrm{~min}$. In terms of $E$. coli disinfection, $0.03 \mathrm{M} \mathrm{Ag-TiO}$ exhibit better performance than its unmodified counterpart, revealing 99.999\% bactericidal activities in 10 mins.

Copyright (C 2022 by Authors, Published by BCREC Group. This is an open access article under the CC BY-SA License (https://creativecommons.org/licenses/by-sa/4.0).

Keywords: Photocatalyst; $\mathrm{TiO}_{2}$ nanotubes; Microplastic; $\mathrm{Ag}-\mathrm{TiO}_{2}$ nanotubes; $\mathrm{Fe}-\mathrm{TiO}_{2}$ nanotubes

How to Cite: Y. Yuwendi, M. Ibadurrohman, S. Setiadi, S. Slamet (2022). Photocatalytic Degradation of Polyeth-

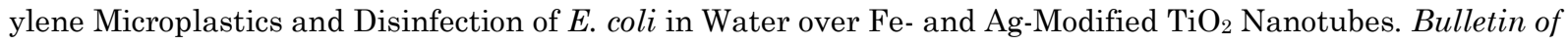
Chemical Reaction Engineering \& Catalysis, 17(2), 263-277 (doi: 10.9767/bcrec.17.2.123400.263-277)

Permalink/DOI: https://doi.org/10.9767/bcrec.17.2.13400.263-277

\section{Introduction}

The prevalent usage of plastics, particularly those with the size of less than $5 \mathrm{~mm}$, (known as microplastics) has become a major environmental problem. Microplastics have been found on tap water, beverages, and commercial salt [1]. Along with the presence of bacteria, such as $E$.

* Corresponding Author.

Email: slamet@che.ui.ac.id (S. Slamet);

Telp: +62-21-7863516, Fax: +62-21-7863515
Coli, microplastics in these products could pose a serious threat, especially if it is ingested by humans. Large-scale research [2] reveals the contamination of microplastics in $93 \%$ bottled water samples taken from nine different countries, with an average concentration of $325 \mathrm{mi}-$ croplastic particles per liter. Microplastics can adsorb toxic contaminants, such as Polychlorobiphenyls (PCBs) which can disrupt the human hormonal system [3], as well as bisphenol A (BPA) that may interrupt the endocrine system and may cause cancer. 
Several technologies have been applied to overcome the uprising of microplastic pollution in water, such as ultrafiltration, coagulation, and reverse osmosis, to name a few [4]. Despite the promising approaches, these techniques still leave microplastic residue after processing. Therefore, the advanced oxidation processes (AOP), which include ozonation, Fenton process, sonolysis, wet-air oxidation, and photocatalysis, are deemed more reliable technological routes to solve the seemingly bottomless environmental problems [5]. Ozonation has indeed been sought to degrade microplastics [6], but its energy-demanding and costly nature has limited its scope of applications. On the other hand, solar-driven photocatalysis, being an effective and cost-effective process, has gained attention from researchers to be applied in a wide range of environmental applications [7-9]. Titania, in particular, is an attractive photocatalyst for this purpose, owing to its low toxicity, excellent stability, and high photoactivity [10]. Converting utilizing photon energy into necessary potentials of charge carriers (electrons and holes), degradation of organic compounds (such as microplastics and microorganisms) can be achieved through the formation of reactive oxygen species (ROS) in a humid, aerobic environment. The degradation of polyethylene microplastics using $\mathrm{TiO}_{2}$-based photocatalysts had been conducted and reported by several authors [11-14]. However, most of the studies used powdered $\mathrm{TiO}_{2}$, the downside of which is the need for post-process filtration to recover the used photocatalysts. Immobilization of Titania in a substrate through the formation of films is hence deemed more practical for the sustainability of the process. Titania with ordered nano-tubular arrays is one of the most attractive nanostructures of titania because of its high specific surface area, photon absorption efficiency, and compatibility with fast electron transport [15]. Previous studies conducted by Ali et al. [16] showed that titania nanotubes could effectively degrade polyethylene film. However, to the best of our knowledge, the degradation of polyethylene microplastics over photo-driven $\mathrm{TiO}_{2}$ nanotube arrays has yet to be explored.

The use of $\mathrm{TiO}_{2}$-based photocatalysts, however, is by no means without drawbacks. Two of the most quoted disadvantages of $\mathrm{TiO}_{2}$ are its wide bandgap and high rate of electron-hole recombination that limits its photocatalytic performance[12-14,17,18]. One of the considerations that can be taken to overcome this weakness is by incorporating metals ions into $\mathrm{TiO}_{2}$ structure [19]. Among the wide range [17] of available choices, $\mathrm{Fe}^{3+}$ was of tremendous interest owing to its similar ionic radii to $\mathrm{Ti}^{4+}$ that facilitates incorporation into the crystal lattice of $\mathrm{TiO}_{2}$ [20-22]. On the other hand, $\mathrm{Ag}$ is also a promising promotor for $\mathrm{TiO}_{2}$ as it is a noble metal that could reduce the recombination rate of the photogenerated electrons and holes through the formation of the Schottky Barrier on the $\mathrm{Ag}-\mathrm{TiO}_{2}$ interface. It is also well documented that $\mathrm{Fe}$ - and Ag-modified $\mathrm{TiO}_{2}$ nanotubes were successfully fabricated through electrochemical anodization of $\mathrm{Ti}$ plates to grow nanotubular structure, which is followed by a successive ionic layer adsorption and reaction (SILAR) method to incorporate $\mathrm{Fe}$ and/or Ag [23-26]. Interestingly, besides being assigned as photocatalysts [23,25], Fe- and Agmodified $\mathrm{TiO}_{2}$ nanotubes fabricated via the anodization-SILAR combined methods were suitable for other applications, e.g. as electrocatalysts [24] and supercapacitors [26]. Despite these virtues, nonetheless, there remain limited studies that compare $\mathrm{Fe}$ and $\mathrm{Ag}$ as promotors for $\mathrm{TiO}_{2}$ nanotubes., especially in degrading microplastics and disinfection of E. Coli. Furthermore, the titania nanotubes used by most researchers are mainly immobilized on rectangular titanium (Ti) plates [27-30].

In this paper, we report our study on the photocatalytic degradation of microplastics using $\mathrm{Ag}^{+}$- and $\mathrm{Fe}^{3+}$-decorated $\mathrm{TiO}_{2}$ nanotubes, as well as the antibacterial test of the composite photocatalysts. The nanotube arrays were formed on a curved plate -mimicking the shell of a cylinder- via an anodization method. $\mathrm{Ag}^{+}$ and $\mathrm{Fe}^{3+}$ were subsequently incorporated into TNT using the SILAR method to improve the photocatalytic properties. In particular, the effects of anodization voltage, $\mathrm{Fe}^{3+}$ concentration, and $\mathrm{Ag}^{+}$concentration on the resultant features of the composites and their performance in terms of microplastic degradation and bacteria disinfection are emphasized.

\section{Materials and Methods}

\subsection{Synthesis of TNT}

Titanium plate (Shaanxi Yunzhong Metal Technology Co., Ltd.) with a thickness of 0.3 $\mathrm{mm}$ was cut into $17 \mathrm{~cm} \times 5 \mathrm{~cm}$ and curved to shape like the shell of a cylinder. It was then mechanically polished with sandpapers and chemically polished in a solution containing hydrogen fluoride (Merck, 40\%), nitric acid (Merck, 65\%), and distilled water (1:3:6). The polished plate was then cleaned using distilled water, sonicated for $10 \mathrm{~min}$, and subsequently dried at ambient temperature. Nanotubular ar- 
rays of $\mathrm{TiO}_{2}$ were generated on Ti plate via an electrochemical anodization method [31], by assigning Ti plate as the anode and platinized $\mathrm{Ti}$ (Shaanxi Yunzhong Metal Technology Co., Ltd.) as the cathode, situated with 1-cm apart between each other. The anodization was carried out under continuous stirring for $45 \mathrm{mins}$ in a $160-\mathrm{mL}$ electrolyte solution containing glycerol (PT. Wiloso), 0.5\% wt $\mathrm{NH}_{4} \mathrm{~F}$ (Merck, $98 \%$ ), and $25 \%$ volume of distilled water at different voltages: $10 \mathrm{~V}, 20 \mathrm{~V}, 30 \mathrm{~V}$, and $40 \mathrm{~V}$ (denoted as TNT 10V, TNT 20V, TNT 30V, and TNT 40V respectively).

\subsection{Doping Method}

The introduction of either $\mathrm{Fe}$ or $\mathrm{Ag}$ dopant into $\mathrm{TiO}_{2}$ nanotubes was done after anodization by a Successive Ionic Layer Adsorption and Reaction (SILAR) method [23-25]. The amorphous TNT was firstly immersed in a $140-\mathrm{mL}$ solution of either $\mathrm{Fe}\left(\mathrm{NO}_{3}\right)_{3}$ (Merck) as $\mathrm{Fe}^{3+}$ precursor or $\mathrm{AgNO}_{3}$ (Merck) as $\mathrm{Ag}^{+}$precursor under continuous stirring for 5 mins. The concentration of the precursor salts were varied as follows: $0.03 \mathrm{M}, 0.06 \mathrm{M}$, or $0.09 \mathrm{M}$ (denoted as 0.03M Fe-TNT, 0.06M Fe-TNT, 0.09M Fe-TNT for Fe-modified TNT and $0.03 \mathrm{M}$ Ag-TNT, 0.06M Ag-TNT, 0.09M Ag-TNT for Ag-modified TNT). It was followed by natural drying at the ambient temperature for $30 \mathrm{~s}$ before being transferred to distilled water for $30 \mathrm{~s}$. This procedure constitutes one SILAR cycle and the operation was repeated for 20 cycles. Finally, the modified TNT was cleaned with distilled water and then annealed at $500{ }^{\circ} \mathrm{C}$ for $3 \mathrm{~h}$ to induce crystallization.

\subsection{Characterizations}

The as-calcined samples were then cut and characterized. The superstructure and morphology of the nanotubes were investigated by Field Emission Scanning Electron Microscope (FESEM, JEOL JIB-4610F). The bandgap is obtained by extrapolating the linear region of the plot to intersect with the $\mathrm{x}$-axis, which marks the estimated bandgap value of any given sample. The crystallite structure of the photocatalyst was identified using an X-ray diffractometer (XRD) with $\mathrm{Cu}$ anode (Ka $1.5406 \AA$ ) as a beam source, operating under $40 \mathrm{kV}$ and 30 $\mathrm{mA}$. The crystallite size was then estimated using the Debye-Scherrer equation. The photoabsorption spectra of the samples were measured using UV-Vis diffuse reflectance spectroscopy (UV-Vis DRS, Agilent Technologies Cary 60 UV-Vis, DRS from Hartrick Scientific with a scan rate of $600 \mathrm{~nm} / \mathrm{min}$ ). Accordingly, the band gap of the photocatalyst samples was estimated using the Kubelka-Munk function:

$$
[F(R) h v]^{1 / 2}=K\left(h v-E_{g}\right)
$$

with:

$$
F(R)=\frac{1-R}{2 R^{2}}
$$

where, $R$ is reflectance, $h v$ is the photon energy, $K$ is a constant for $\mathrm{TiO}_{2}$, and $E_{g}$ is the band gap. The parameter $[F(R) h v]^{1 / 2}$ is assigned as the $\mathrm{y}$-axis and $h v$ as the $\mathrm{x}$-axis.

\subsection{Microplastic Photocatalytic Degradation and E. coli Disinfection Test}

The effectiveness of the photocatalyst samples was evaluated in terms of degradation of polyethylene microplastics and disinfection of $E$. Coli. The tests were carried out inside a photoreactor with UVC (Yamano 11W, $\lambda=254$ $\mathrm{nm})$ as the photon source. The total plate count (TPC) method was used to analyze the E. coli colony over time. On the other hand, An amount of $25 \mathrm{mg}$ of polyethylene scrub microplastics (100 - 150 microns) and $250 \mathrm{~mL}$ of distilled water was added into the reactor prior to irradiation. During irradiation, the photoreactor was wrapped with aluminum foil, while continuously stirred. The degradation of polyethylene microplastics was observed by filtering them using Whatmann Filter 42, then measuring its weight loss over time using a gravimetry method by weighing the mass of microplastics before and after photodegradation, according to the Equation (1).

$$
\frac{\left(\begin{array}{l}
\text { Weight loss of } \\
\text { microplastics }
\end{array}\right)(\%)=}{\left(\begin{array}{l}
\text { Weight before } \\
\text { photodegradation }
\end{array}\right)-\left(\begin{array}{l}
\text { Weight after } \\
\text { photodegradation }
\end{array}\right)} \times 100 \%
$$

\section{Results and Discussion}

\subsection{Photocatalyst Characterization}

Figures 1 and 2, respectively, show the corresponding surface morphology and crosssectional view of titania nanotubes at different anodization voltages. At the low anodization voltage of $10 \mathrm{~V}$, the nanotube arrays have not yet uniformly formed. The nanotubular structure is gradually formed as the voltage becomes higher. It was also found that the uniformity of the tubes is better at high voltages, as highly ordered nanotube arrays grow on the plate. Important parameters of the superstructure, namely tube diameter, wall thickness, and tube length, can accordingly be de- 

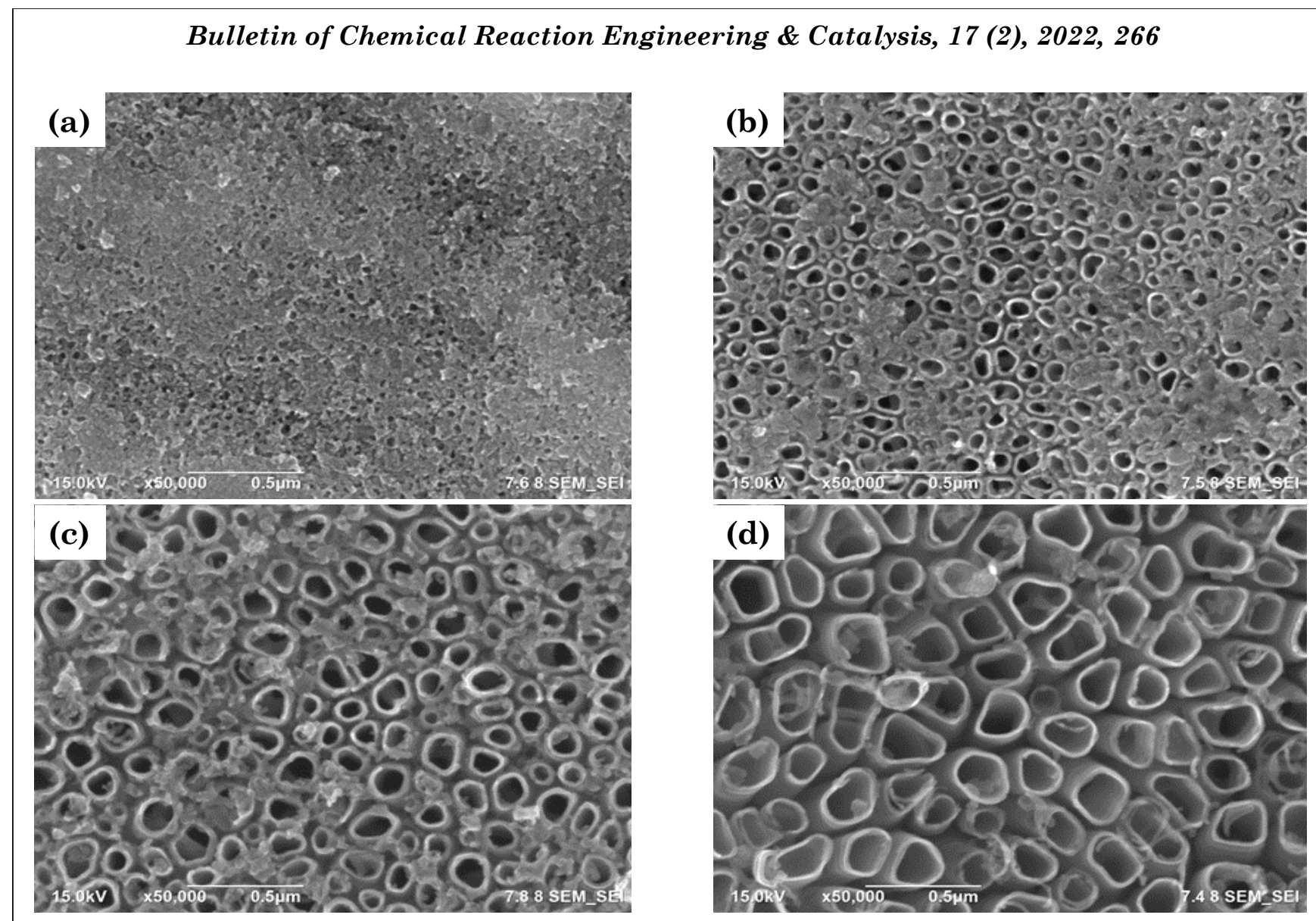

Figure 1. Scanning-electron micrographs displaying surface morphology of (a) TNT 10V, (b) TNT 20V, (c) TNT 30V, (d) TNT 40V.
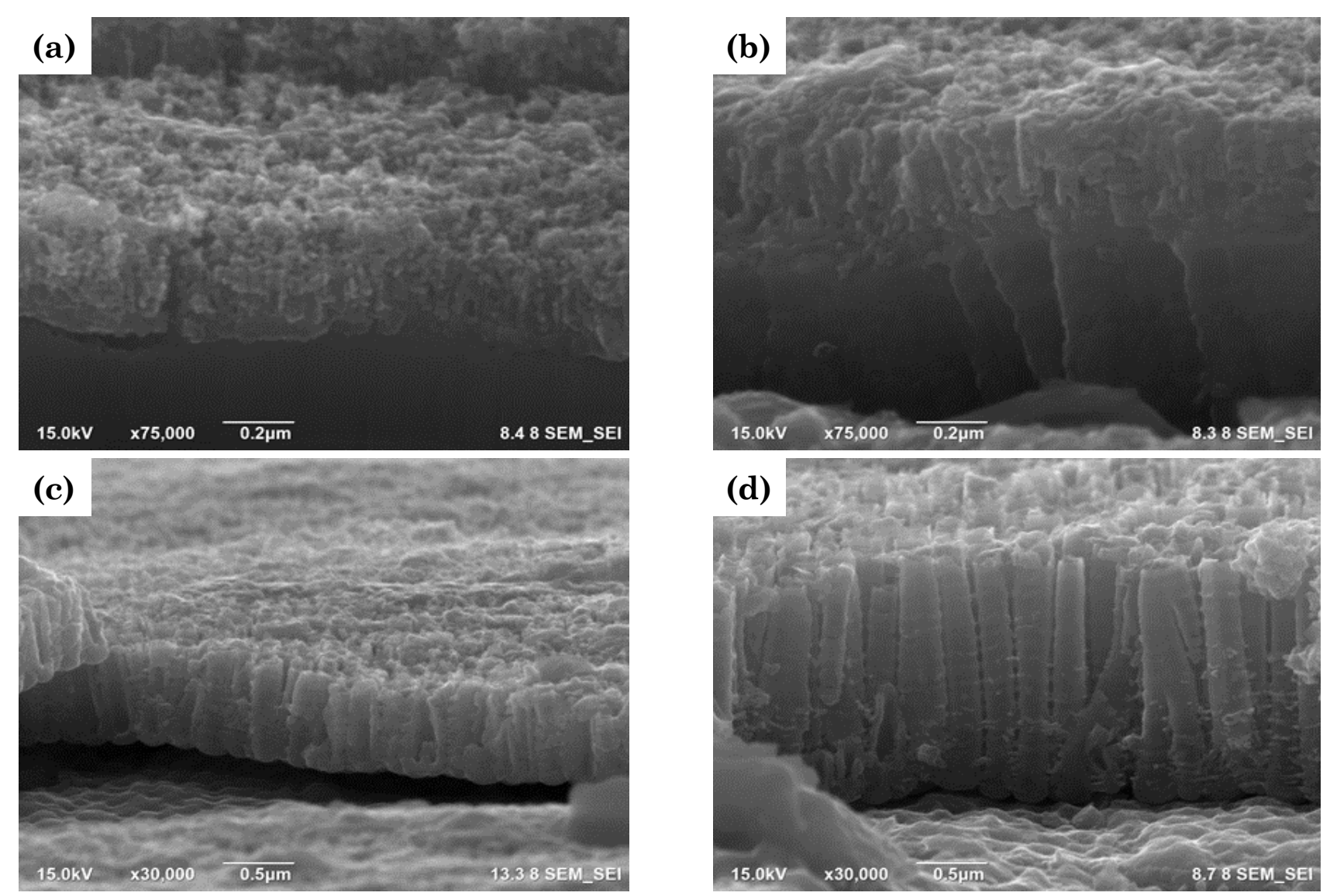

Figure 2. Cross sectional micrographs of (a) TNT 10V, (b) TNT 20V, (c) TNT 30V, (d) TNT 40V. 


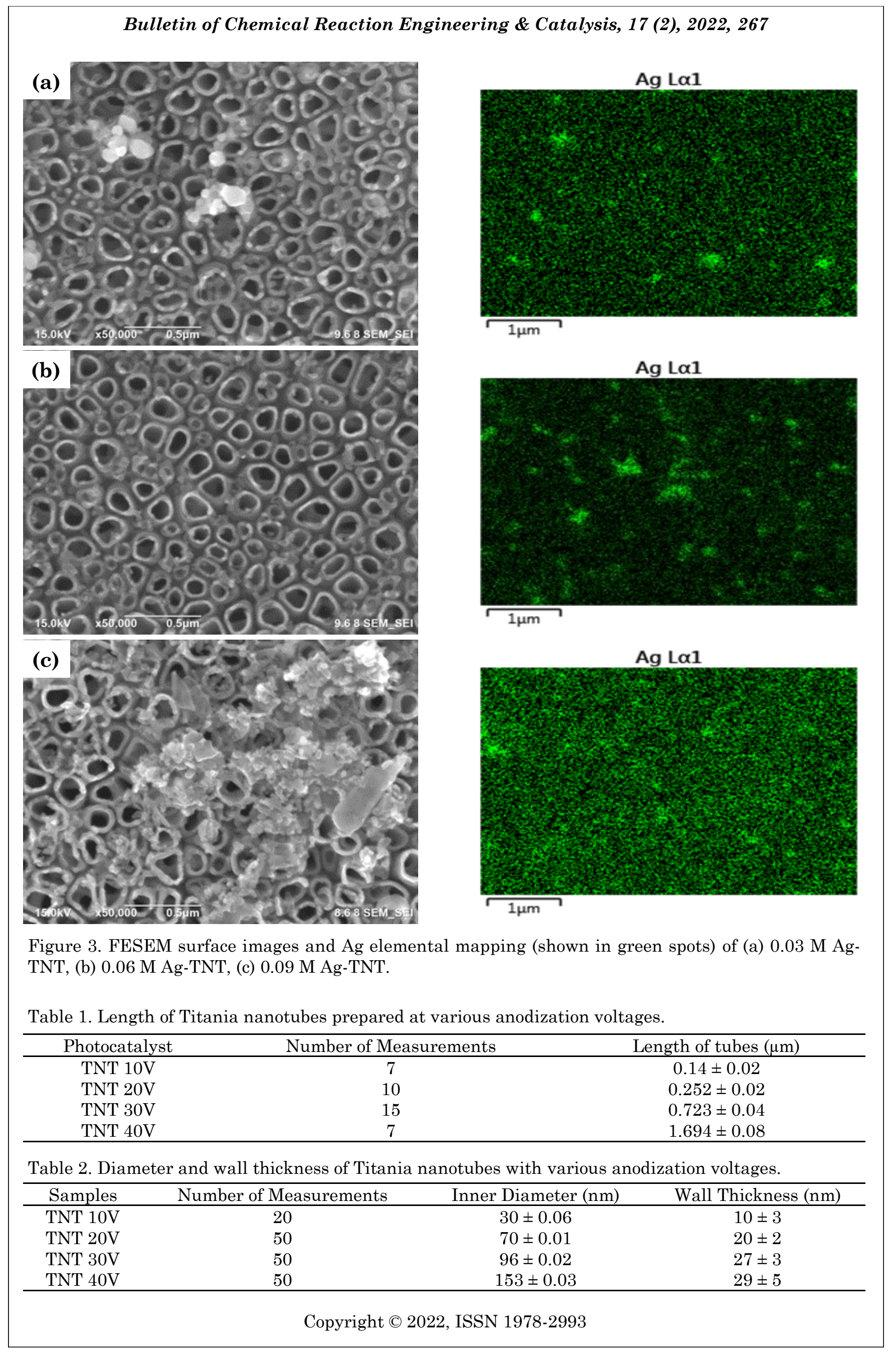


duced from the micrographs, summarized in Tables 1 and 2. It is evident that all of nanotubes diameter, wall thickness, and height are almost linearly correlated with the anodization voltage. In terms of nanotube inner diameter, increasing anodic voltage from $10 \mathrm{~V}$ to $40 \mathrm{~V}$ leads to larger pores from $30 \mathrm{~nm}$ to $153 \mathrm{~nm}$, while the wall becomes thicker from $10 \mathrm{~nm}$ to $29 \mathrm{~nm}$. The tube also elongates from $140 \mathrm{~nm}$ to $1.69 \mu \mathrm{m}$ following the increase of anodization voltage from $10 \mathrm{~V}$ to $40 \mathrm{~V}$.

The effect of anodization voltage on the average diameter of nanotubes can be related to the number of pits formed in the initial stage of anodization. As the anodizing voltage becomes higher, the electric field between the anode and the cathode increases so that the chemical dissolution (i.e. the formation of $\left(\mathrm{TiF}_{6}\right)^{2-}$ complex) shall also increase, forming more pits. These pits form larger pores, resulting in larger nanotubes diameter. Concurrently, at higher anodizing voltages, the high chemical dissolution becomes more prominent, producing longer nanotubes as a result of the faster pore deepening rate [32]. The elongation is due to the increased driving force for
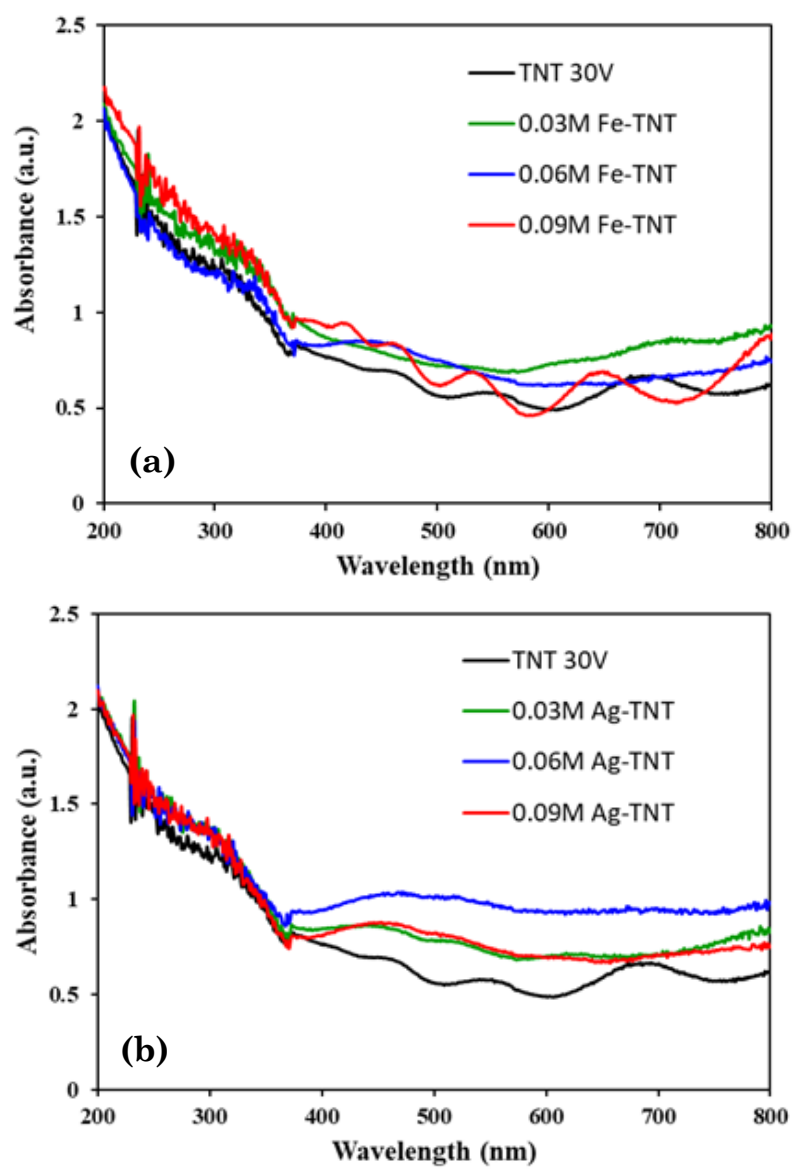

Figure 4. UV-Vis Absorption Spectra of (a) Femodified TNT for various contents, (b) Agmodified TNT for various contents. ionic species $\left(\mathrm{H}^{+}, \mathrm{F}^{-}\right.$, and $\left.\mathrm{O}^{2-}\right)$ to transport through the barrier layer at the bottom of the nanotube under electric field, which results in faster movement of the $\mathrm{Ti} / \mathrm{TiO}_{2}$ interface into the Ti metal [33]. As discussed in the next section, the TNT samples prepared at $30 \mathrm{~V}$ and 40 $\mathrm{V}$ show superior activities than the samples anodized at lower voltages. For the purpose of further modifications and characterizations, the sample anodized at $30 \mathrm{~V}$ will be used because, at this voltage, the photocatalytic properties are sufficiently high and the use of higher voltage $(40 \mathrm{~V})$ does not offer further improvements.

Figure 3 displays FESEM micrographs of Ag-doped $\mathrm{TiO}_{2}$ nanotubes at different concentrations of the precursor salt, along with the elemental mapping of Ag. In all cases, the Ag signals are observed which suggest the successful deposition of $\mathrm{Ag}$ particles on the TNT substrate. It can be inferred from Figure 6(a) that, for $0.03 \mathrm{M} \mathrm{Ag-TNT} \mathrm{sample,} \mathrm{Ag}$ particles disperse throughout the superficial feature of the nanotubes rather uniformly. Increasing the concentration of $\mathrm{Ag}$ precursor salt to $0.06 \mathrm{M}$ leads to slight agglomeration (Figure 6(b)), while aggregation of Ag particles becomes quite noticeable in the case of $0.09 \mathrm{M} \mathrm{Ag-TNT} \mathrm{sam-}$ ple (Figure 6(c)), covering the nanotube pores to some extent. EDS analysis also confirms the observed $\mathrm{Ag}$ content of $1 \% \mathrm{wt}, 2.5 \% \mathrm{wt}$, and $2.7 \%$ wt for $0.03 \mathrm{M} \mathrm{Ag-TNT,} 0.06 \mathrm{M} \mathrm{Ag-TNT,}$ and $0.09 \mathrm{M} \mathrm{Ag-TNT}$, respectively.

Figure 4 represents the absorption spectra of the synthesized TNT samples in the case of $30-\mathrm{V}$ anodization voltage, for unmodified TNT and those modified with $\mathrm{Fe}$ and $\mathrm{Ag}$. It is shown that the addition of either $\mathrm{Fe}$ or $\mathrm{Ag}$ into $\mathrm{TiO}_{2}$ nanotubes increases photocatalyst absorption in the visible light region. The increasing visible light absorption on both $\mathrm{Ag}$ - and $\mathrm{Fe}$ -

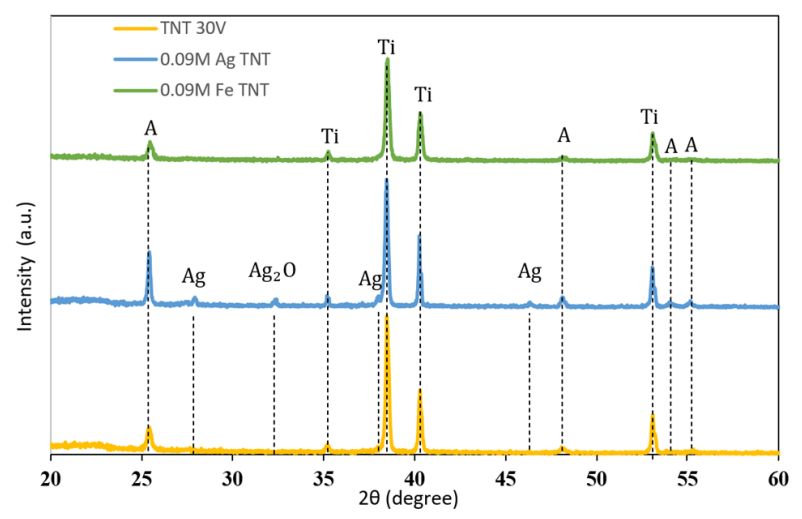

Figure 5. X-Ray Diffraction patterns of TNT 30 V, 0.09 M Fe-TNT, and 0.09 M Ag-TNT. 
modified $\mathrm{TiO}_{2}$ samples could be explained by the introduction of impurity levels in the band structure of $\mathrm{TiO}_{2}$ as a result of the incorporation of doping ions in the crystal lattice. In addition, in the case of $\mathrm{Ag}$, the visible light absorption could also be originated from the collective oscillations of free electrons on $\mathrm{Ag}$ surfaces when interacting with visible electromagnetic radiation [34]. Table 3 summarizes the band gap of the prepared samples, in which it is informative that TNT has a bandgap of $3.15 \mathrm{eV}$, which is close to the known band gap for anatase $(3.2 \mathrm{eV})$. Importantly, the addition of either $\mathrm{Fe}$ or $\mathrm{Ag}$ on $\mathrm{TiO}_{2}$ nanotubes leads to slight bandgap narrowing and causes a redshift in the light absorption capacity.

$\mathrm{X}$-ray diffractometry (XRD) analysis (Figure 5) was conducted to characterize the crystallite properties of the unmodified TNT, $0.09 \mathrm{M} \mathrm{Fe}$ TNT, and 0.09 M Ag-TNT. For the purpose of XRD analysis, the metal-doped TNT samples with the highest concentration of $\mathrm{Fe}$ and $\mathrm{Ag}$ precursors are chosen to observe the possibility of signals attributable to $\mathrm{Fe}$ and $\mathrm{Ag}$ crystals. Accordingly, the diffractograms are illustrated in Figure 11, revealing the diffraction signals at $2 \theta$ of $25.4^{\circ}, 48.2^{\circ}, 54.1^{\circ}$, and $55.2^{\circ}$ which

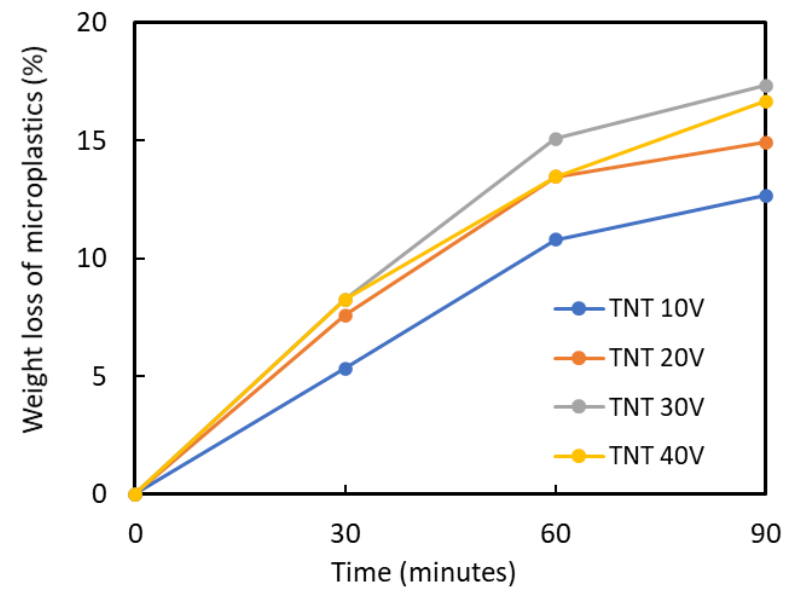

Figure 6. Profile of weight loss of microplastics as a function of illumination time in the presence of TNT samples prepared at different anodization voltages. infer that the TNT samples are of the anatase phase with the crystallite orientations of (101), (200), (105), and (221), in accordance with JCPDS No. 21-1272. No peak associated with the rutile or brookite phase could be identified, which is expected because the annealing temperature is not so high that the formation of other phases than that of anatase can be induced. Additionally, diffraction peaks at $2 \theta=$ $35.2^{\circ}, 38.5^{\circ}, 40.3^{\circ}$, and $53.1^{\circ}$ are attributable to the titanium substrate with the indices of (100), (002), (101), and (102) according to JCPDS No. 44-1294.

In the case of $0.09 \mathrm{M} \mathrm{Ag}$ TNT sample, three signals are observed at $2 \theta=38.01^{\circ}, 46.3^{\circ}$, and $27.9^{\circ}$, conforming to planes (111), (200), (210) of metallic Ag, as per JCPDS No. 04-0783 [35,36]. An additional peak at $2 \theta=32.4^{\circ}$ is also observed, attributable to $\mathrm{Ag}_{2} \mathrm{O}$ based on JCPDS 41-1104. Unlike $\mathrm{Fe}^{3+}$, which has a comparable radius to that of $\mathrm{Ti}^{4+}$, the ionic radius of $\mathrm{Ag}^{+}(1.26 \AA)$ is higher than that of $\mathrm{Ti}^{4+}$. The incorporation of $\mathrm{Ag}^{+}$in $\mathrm{TiO}_{2}$ is hence difficult to achieve because of these inherent properties [37]. Consequently, the majority of $\mathrm{Ag}$ is expected to be dispersed on the photocatalyst surface. On the other hand, the XRD patterns for the Fe-modified samples reveal no characteristic signals attributed to $\mathrm{Fe}$ species. This could be attributed to the limitation of XRD detection, well dispersion of $\mathrm{Fe}$, or because $\mathrm{Fe}^{3+}$ is successfully incorporated into $\mathrm{TiO}_{2}$ lattice. Applying the Scherrer equation to estimate the crystallite size of anatase with (101) plane, the $\mathrm{TiO}_{2}$ crystallite size for TNT, 0.09M Fe-TNT, and 0.09M AgTNT are found to be $25.49 \mathrm{~nm}, 23.97 \mathrm{~nm}$, and $44.25 \mathrm{~nm}$, respectively [38].

\subsection{Microplastic Degradation}

The photocatalytic degradation of polyethylene microplastics is illustrated in Figure 6, presenting the degree of degradation (\% weight loss) as a function of time for TNT samples anodized at different voltages. The overall performance of the photocatalysts is expected to be driven by the degree of nanotube for-

Table 3. Bandgap estimation of the synthesized photocatalysts.

\begin{tabular}{ccc}
\hline Photocatalyst & Band-gap energy $(\mathrm{eV})$ & Wavelength $(\mathrm{nm})$ \\
\hline TNT 30V & 3.15 & 393.65 \\
0.03 Ag-TNT & 3.07 & 403.91 \\
0.06 Ag-TNT & 3.04 & 407.89 \\
0.09 Ag-TNT & 3 & 413.33 \\
0.03 Fe-TNT & 3.1 & 400.00 \\
0.06 Fe-TNT & 3.08 & 402.60 \\
0.09 Fe-TNT & 3.06 & 405.23 \\
\hline
\end{tabular}


mation, namely the pore diameter and the tube length. As informative in Figures 1 and 2, applying a higher voltage of anodization results in more established and ordered nanotube arrays [32]. The photocatalytic properties seem to be consistent with this finding as the samples prepared under high anodization voltages offer better performance in terms of microplastic degradation. It is inferred from Figure 6 that TNT samples prepared at $30 \mathrm{~V}$ and $40 \mathrm{~V}$ could induce weight loss of microplastics up to $17 \%$ after 90 mins, while those prepared at $10 \mathrm{~V}$ and $20 \mathrm{~V}$ could only maintain degradation of $15 \%$ and $12 \%$, respectively, for the same duration. Expectedly, larger pore diameter and longer nanotubes constitute higher specific surface area, resulting in better photon absorption and more effective carrier transport which eventually ensures higher photocatalytic performance.

Although the size of microplastics is too large to diffuse into TNT pores, their removal could be driven by the formation of reactive oxygen species (ROS). ROS are produced by means of redox reactions driven by photogenerated charge carriers. The first step of microplastic degradation involves the generation of electrons and holes due to interaction between photons and $\mathrm{TiO}_{2}$ (Equation 3), which are subsequently responsible for the production of hydroxyl radicals (Equation 4) and superoxides (Equation 5). What follows are a series of reactions producing more ROS [39], which might involve the processes described in Equations 5-8. Once ROS are generated, the abstraction of polyethylene alkyl chains by hydroxyl radicals to form alkyl radicals occurs, as shown by Equation 9. Afterward, the propagation is in effect, leading to chain breaking of polyethylene groups. Finally, intermediate groups are generated, which can react further to produce $\mathrm{CO}_{2}$ and $\mathrm{H}_{2} \mathrm{O}$ as the

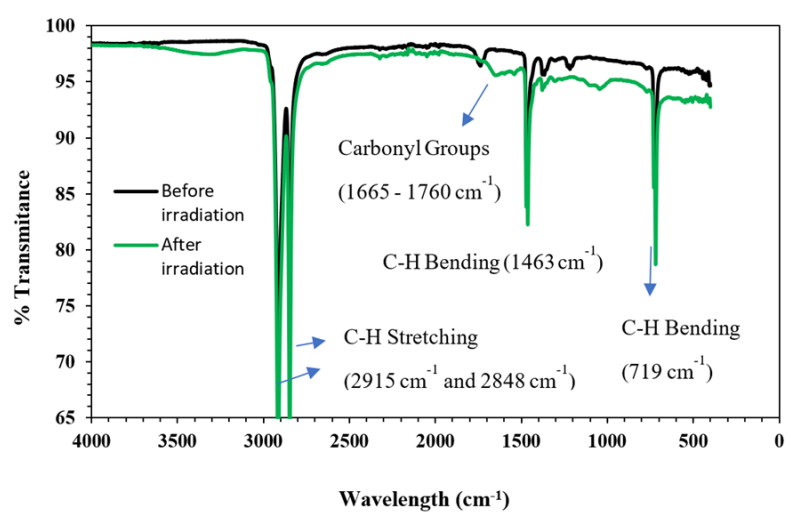

Figure 7. FTIR Spectra of microplastic samples before and after photocatalytic degradation. final products, as shown by Equations 10-17 [16,40-42].

$$
\begin{aligned}
& \mathrm{TiO}_{2}+h v \rightarrow \mathrm{h}^{+}+\mathrm{e}^{-} \\
& \mathrm{H}_{2} \mathrm{O}+\mathrm{h}^{+} \rightarrow \cdot \mathrm{OH}+\mathrm{H}^{+} \\
& \mathrm{O}_{2}+\mathrm{e}^{-} \rightarrow \mathrm{O}_{2}^{--} \\
& \mathrm{O}_{2}^{-} \cdot+\mathrm{H}_{2} \mathrm{O} \rightarrow \mathrm{HO}_{2}^{-} \cdot+\mathrm{OH}^{-} \\
& 2 \mathrm{HO}_{2} \cdot \rightarrow \mathrm{H}_{2} \mathrm{O}_{2}+\mathrm{O}_{2} \\
& \mathrm{H}_{2} \mathrm{O}_{2}+h v \rightarrow 2 \cdot \mathrm{OH}
\end{aligned}
$$

Initiation:

$$
\sim \mathrm{CH}_{2} \mathrm{CH}_{2} \sim+\cdot \mathrm{OH} \rightarrow \sim \cdot \mathrm{CHCH}_{2} \sim+\mathrm{H}_{2} \mathrm{O}
$$

Propagation:

$$
\begin{aligned}
& \sim \mathrm{CHCH}_{2} \sim+\mathrm{O}_{2} \rightarrow \sim \mathrm{CH}(\cdot \mathrm{OO}) \mathrm{CH}_{2} \sim \\
& \sim \mathrm{CH}(\cdot \mathrm{OO}) \mathrm{CH}_{2} \sim+\sim \mathrm{CH}_{2} \mathrm{CH}_{2} \sim \\
& \quad \rightarrow \sim \mathrm{CH}(\mathrm{OOH}) \mathrm{CH}_{2} \sim+\sim \mathrm{CH}_{2} \cdot \mathrm{CH} \sim \\
& \sim \mathrm{CH}(\mathrm{OOH}) \mathrm{CH}_{2} \sim \stackrel{h v}{\longrightarrow} \sim \mathrm{CH} \cdot \mathrm{OCH}_{2} \sim+\cdot \mathrm{OH} \\
& \sim \mathrm{CH} \cdot \mathrm{OCH}_{2} \sim \rightarrow \sim \mathrm{CHO}+\cdot \mathrm{CH}_{2} \mathrm{CH}_{2} \sim
\end{aligned}
$$

Formation of carboxylic acid, aldehyde, and ketone:

$$
\begin{aligned}
& \cdot \mathrm{CH}_{2} \mathrm{CH}_{2} \sim+\mathrm{O}_{2} \stackrel{\mathrm{TiO}_{2}, h v}{\longrightarrow} \sim \mathrm{CH}_{2} \mathrm{COOH} \\
& +\mathrm{HOCCH}_{2} \sim+\sim \mathrm{CH}_{2} \mathrm{OCCH}_{2} \sim
\end{aligned}
$$

Norrish Type I reaction:

$$
\sim \mathrm{CH}_{2} \mathrm{OCCH}_{2} \sim \stackrel{h v}{\longrightarrow} \sim \mathrm{CH}_{2} \mathrm{OC} \cdot+\cdot \mathrm{CH}_{2} \sim
$$

Norrish Type II reaction (formation of vinyl from ketone):

$$
\begin{aligned}
\sim \mathrm{CH}_{2} \mathrm{OCCH}_{2} \mathrm{CH}_{2} \mathrm{CH}_{2} \sim \stackrel{h v}{\longrightarrow} \sim \mathrm{CH}_{2} \mathrm{OCCH}_{2} \\
+\mathrm{CH}_{2}=\mathrm{CH} \sim
\end{aligned}
$$

Mineralization:

$$
\begin{aligned}
& \sim \mathrm{CH}_{2} \mathrm{COOH}+\mathrm{OCCH}_{2} \sim+\sim \mathrm{CH}_{2} \mathrm{OCCH}_{2} \sim+\mathrm{O}_{2} \\
& \stackrel{\mathrm{CO}_{2}}{\longrightarrow}+\mathrm{H}_{2} \mathrm{O}
\end{aligned}
$$

Figure 7 shows FTIR spectra of a microplastic sample before and after photocatalytic degradation. Four strong peaks associated with $\mathrm{C}-\mathrm{H}$ stretching $\left(2915 \mathrm{~cm}^{-1}\right.$ and $\left.2848 \mathrm{~cm}^{-1}\right)$ and $\mathrm{C}-\mathrm{H}$ bending $\left(1463 \mathrm{~cm}^{-1}\right.$ and $\left.719 \mathrm{~cm}^{-1}\right)$ confirm the characteristics of polyethylene FTIR spectra. For the sample examined after the photocatalytic reactions, a signal attributable to the formation of carbonyl groups is observed in the range of $1665-1760 \mathrm{~cm}^{-1}$, indicating the existence of intermediate products from the photocatalytic degradation of microplastics. Furthermore, the surface morphology of microplastics before and after photocatalytic degradation was also elucidated using an optical microscope. It is observable that, after degradation, the surface of microplastics is ruptured and becomes more irregular in shape as compared to its original conditions. This result is consistent with the observed weight loss of microplastics over time, which can be 
expected due to the conversion of polyethylene into harmless products $\left(\mathrm{CO}_{2}\right.$ and $\left.\mathrm{H}_{2} \mathrm{O}\right)$. As the final product of the degradation is in the gas phase, it does not contribute to the final weight of the microplastics.

The photographs of microplastics before and after photocatalytic reaction can be seen in Figure 8. Figure 9(a) depicts the weight loss of microplastics as a function of illumination time on Fe-modified TNT. It can be seen that the photocatalytic performances of all Fe-modified

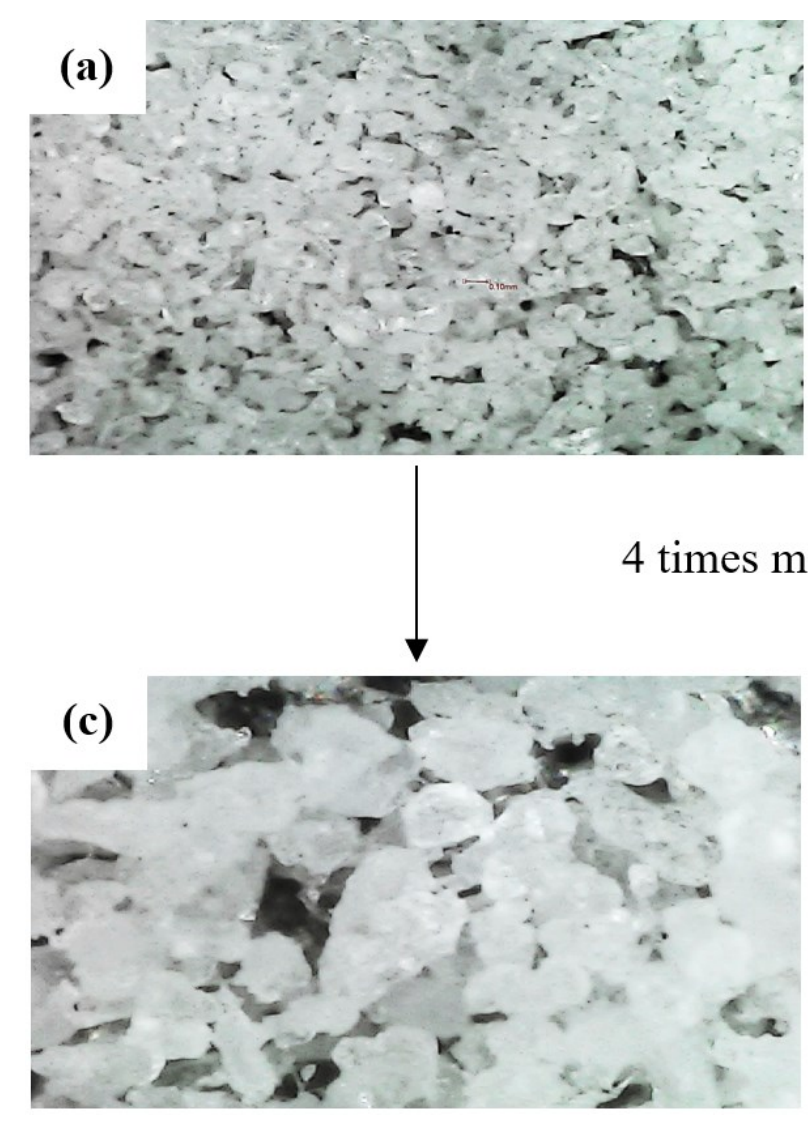

TNT are inferior to that of their unmodified counterpart. In the use of the unmodified TNT, around $17 \%$ weight loss of microplastics was obtained, while the Fe-modified samples could only maintain $6-9 \%$ of microplastic degradation. This is presumably because the concentration of Fe-modified on TNT is too high. $\mathrm{Fe}^{3+}$ can act as both electron trap and hole trap by forming $\mathrm{Fe}^{2+}$ or $\mathrm{Fe}^{4+}$, respectively, which may potentially improve photocatalytic performance (Equations 18-20). However, if

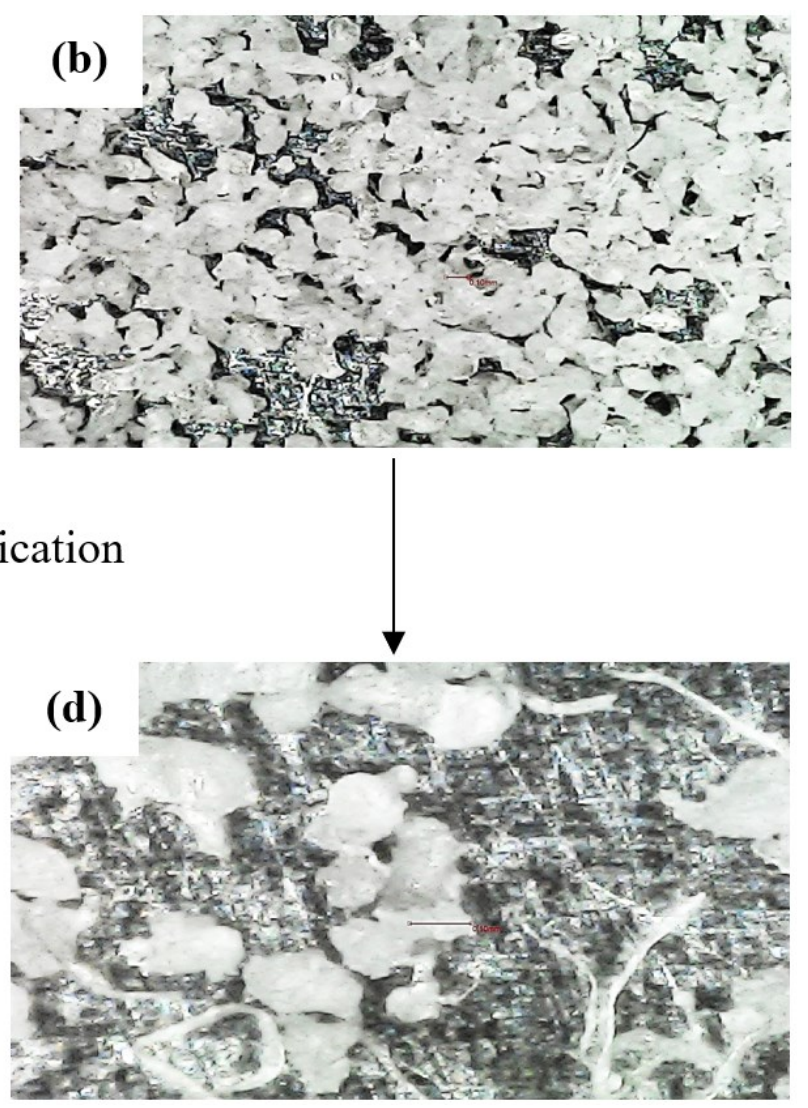

Figure 8. Imaging of digital microscopes displaying the morphology of polyethylene microplastics for (a), (b) before photocatalytic degradation (c), (d) after 120-min photocatalytic.
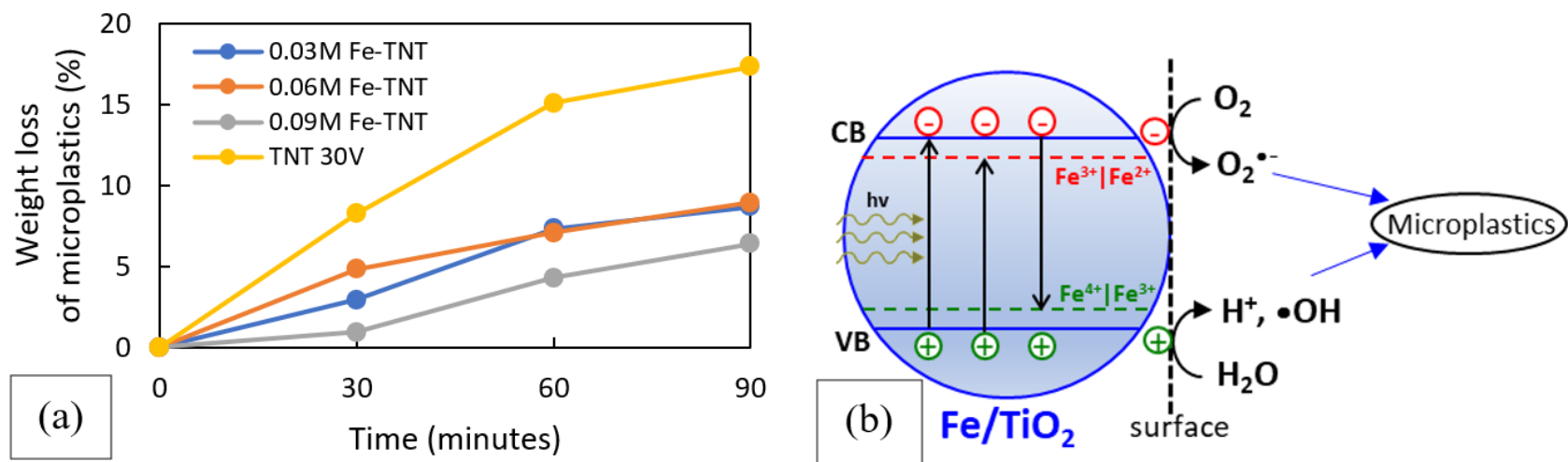

Figure 9. Photocatalytic degradation of microplastics: (a) Profile of weight loss of microplastics as a function of time for Fe-modified TNT samples; (b) Schematic diagram of $\mathrm{Fe}^{3+}$-mediated separation and recombination of photo-charge carriers in the photocatalytic degradation of microplastics. 
the amount is too abundant, Fe may rather act as recombination centers [43], hindering photocatalytic activities (Equations 21 and 22). In addition, as displayed in Table 3, increasing $\mathrm{Fe}$ content leads to slight decreases in bandgap. Indeed, a lower bandgap is beneficial for visible light absorption, but it also induces higher recombination [44]. Since the photon source used in the present experiments illuminates UV, the effect of visible light absorption is superimposed, while the side effect of recombination retains. The schematic diagram elaborating the competitive processes between trapping and recombination offered by the presence of $\mathrm{Fe}$ in Fe-modified $\mathrm{TiO}_{2}$ is illustrative in Figure 9(b).

Photogeneration of electron-hole pair by $\mathrm{Fe}$ modified $\mathrm{TiO}_{2}$ :

$\mathrm{Fe}-\mathrm{TiO}_{2}+h v(\mathrm{UV}) \rightarrow \mathrm{e}^{-}+\mathrm{h}^{+}$

$\mathrm{Fe}^{3+}$ reduction by electron (electron trap) :

$\mathrm{Fe}^{3+}+\mathrm{e}^{-} \rightarrow \mathrm{Fe}^{2+}$

$\mathrm{Fe}^{3+}$ oxidation by hole (hole trap):

$\mathrm{Fe}^{3+}+\mathrm{h}^{+} \rightarrow \mathrm{Fe}^{4+}$

Electron-hole Recombination through $\mathrm{Fe}^{2+}$ oxidation :

$\mathrm{Fe}^{2+}+\mathrm{h}^{+} \rightarrow \mathrm{Fe}^{3+}$

Electron-hole Recombination through $\mathrm{Fe}^{4+}$ reduction:

$$
\mathrm{Fe}^{4+}+\mathrm{e}^{-} \rightarrow \mathrm{Fe}^{3+}
$$

According to the crystal field theory, both $\mathrm{Fe}^{2+}$ and $\mathrm{Fe}^{4+}$ are relatively unstable compared to $\mathrm{Fe}^{3+}$ [43]. They tend to revert to $\mathrm{Fe}^{3+}$ due to the loss of $\mathrm{d}^{5}$ electronic configuration. These reactions can compete with either hydroxyl or superoxide formation. The high concentration of $\mathrm{Fe}$ dopant in the photocatalyst increases the possibility of multiple trappings [45]. The high amount of $\mathrm{Fe}^{3+}$ doped on $\mathrm{TiO}_{2}$ reduces the distance between trapping sites [46], which is
$\mathrm{Fe}^{3+}$ in this case. $\mathrm{Fe}^{3+}$ is then believed to mediate the recombination between electrons and holes before they can reach the photocatalyst surface, depriving the photocatalytic degradation of microplastics. The negative effects caused by Fe dopant were also found by Zhu et al. [45] and Sood et al. [47]. At suitable concentrations, the addition of $\mathrm{Fe}^{3+}$ dopant can improve the performance of the photocatalyst by increasing the radical/ROS species formed, which had been reported by other authors [4850]. The beneficial effects of $\mathrm{Fe}^{3+}$ as a dopant are expressed in Equations 23 to 26. However, the interfacial charge involving $\mathrm{Fe}^{3+}$ is valid only when $\mathrm{Fe}^{3+}$ is located close to the surface sites [48].

Electron transfer from $\mathrm{Fe}^{2+}$ to adsorbed oxygen: $\mathrm{Fe}^{2+}+\mathrm{O}_{2} \rightarrow \mathrm{Fe}^{3+}+\mathrm{O}_{2}{ }^{-}$

Electron transfer from $\mathrm{Fe} 3+$ to the neighboring $\mathrm{Ti}^{4+}$ :

$$
\mathrm{Fe}^{2+}+\mathrm{Ti}^{4+} \rightarrow \mathrm{Fe}^{3+}+\mathrm{Ti}^{3+}
$$

Reaction between $\mathrm{Fe}^{4+}$ with adsorbed $\mathrm{OH}^{-}$:

$$
\mathrm{Fe}^{4+}+\mathrm{OH}^{-} \rightarrow \mathrm{Fe}^{3+}+\cdot \mathrm{OH}
$$

Interfacial electron transfer from $\mathrm{Ti}^{3+}$ to adsorbed oxygen:

$$
\mathrm{Ti}^{3+}+\mathrm{O}_{2} \rightarrow \mathrm{Ti}^{4+}+\mathrm{O}_{2}{ }^{-}
$$

Figure 10(a) shows the microplastic degradation as a function of time on $\mathrm{Ag}$ modified TNT. It can be seen that the addition of $\mathrm{Ag}^{+}$at a concentration of $0.03 \mathrm{M}$ had a positive impact on the microplastic degradation performance of TNT. As a noble metal, Ag has a lower Fermi level than $\mathrm{TiO}_{2}$ semiconductor. Based on the direction of electron stability, electrons flow from the semiconductor to the metal. This flow continues until the Fermi level of $\mathrm{Ag}$ and semiconductor reaches equilibrium. This phenomenon makes $\mathrm{Ag}$ act
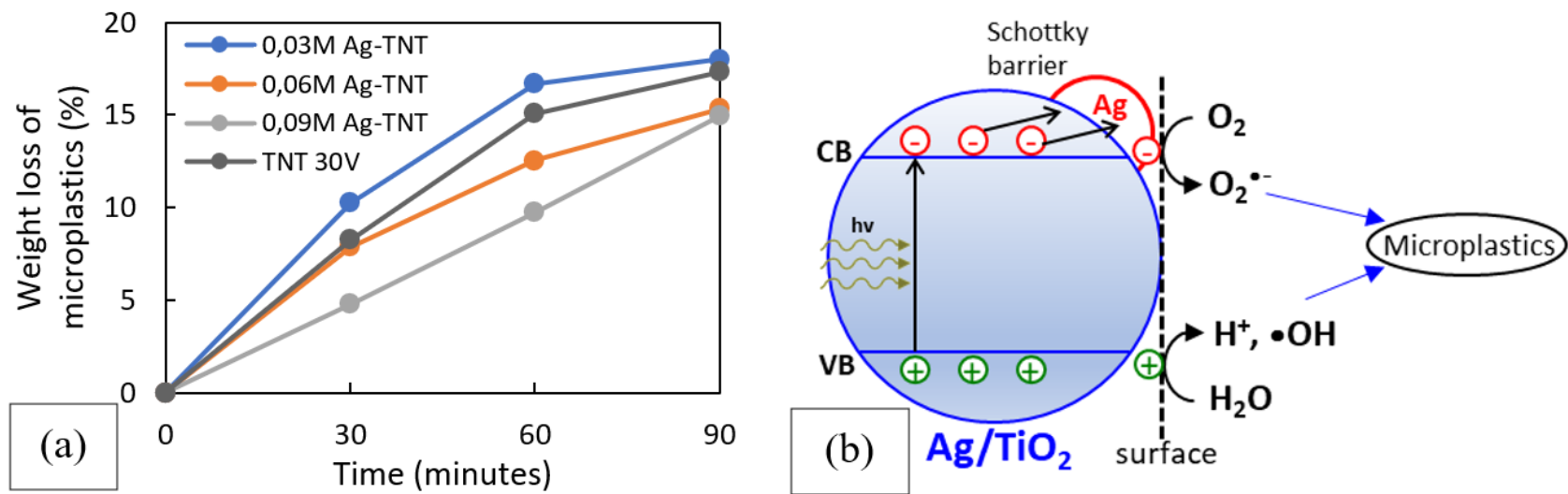

Figure 10. Photocatalytic degradation of microplastics: (a) Profile of weight loss of microplastics as a function of time for Fe-modified TNT; (b) Schematic diagram of $\mathrm{Fe}^{3+}$-mediated separation and recombination of photo-charge carriers in the photocatalytic degradation of microplastics. 
as an electron trapper by forming Schottky Barrier. The Schottky barrier hinders the reverse flow of electrons to the semiconductor, thus the electron-hole recombination can be prevented [51]. The schematic diagram in Figure $10(\mathrm{~b})$ is intended to attempt at elucidating this effect. Furthermore, the presence of Ag nanoparticles on $\mathrm{TiO}_{2}$ surface contribute to the formation of $\cdot \mathrm{O}_{2}^{-}$, as expressed in Equations (27) to (29):

$$
\mathrm{Ag}-\mathrm{TiO}_{2}+h v(\mathrm{UV}) \rightarrow \mathrm{Ag}-\mathrm{TiO}_{2}\left(\mathrm{e}^{-}+\mathrm{h}^{+}\right)
$$

Electron transfer from $\mathrm{TiO}_{2}$ conduction band to Ag through Schottky Junction :

$$
\mathrm{Ag}_{-} \mathrm{TiO}_{2}\left(\mathrm{e}^{-}\right) \rightarrow \mathrm{TiO}_{2} / \mathrm{Ag}\left(\mathrm{e}^{-}\right)
$$

Reduction of adsorbed oxygen on Ag surface:

$$
\mathrm{TiO}_{2}-\mathrm{Ag}\left(\mathrm{e}^{-}\right)+\mathrm{O}_{2} \rightarrow \mathrm{TiO}_{2}-\mathrm{Ag}+\cdot \mathrm{O}_{2}{ }^{-}
$$

Importantly, further increase in $\mathrm{Ag}$ content for the cases of $0.06 \mathrm{M} \mathrm{Ag-TNT}$ and $0.09 \mathrm{M} \mathrm{Ag-}$ TNT is detrimental to microplastic degradation performances, which are even poorer than that achieved by the unmodified TNT. The diminished photocatalytic activities at higher Ag concentrations are thought to be due to the formation of $\mathrm{Ag}$ clusters on the surface of the photocatalyst, thereby reducing the active site of Titania in absorbing photons. Furthermore, as confirmed by XRD patterns, the presence of $\mathrm{Ag}_{2} \mathrm{O}$ could cause photocatalysts to suffer from poor activities. It is well documented that the conduction band of $\mathrm{Ag}_{2} \mathrm{O}$ lies below (more positive than) the standard $\mathrm{O}_{2} / \cdot \mathrm{O}_{2}{ }^{-}$redox potential, so that the electrons in the $\mathrm{Ag}_{2} \mathrm{O}$ conduction band are lack thermodynamic requirements to reduce the adsorbed $\mathrm{O}_{2}$ on the $\mathrm{Ag}_{2} \mathrm{O}$ surface [52-55]. With the same line of arguments, holes in the $\mathrm{Ag}_{2} \mathrm{O}$ valence band are thermodynamically incapable of oxidizing the

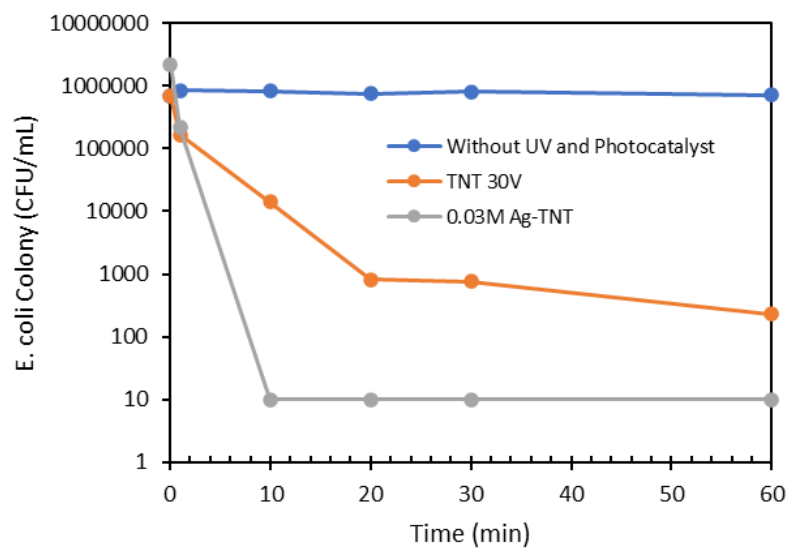

Figure 11. Profile of $E$. coli colony as a function of time under dark and illuminated conditions, with two different photocatalysts. adsorbed $\mathrm{H}_{2} \mathrm{O}$ on the $\mathrm{Ag}_{2} \mathrm{O}$ surface because - $\mathrm{OH} / \mathrm{H}_{2} \mathrm{O}$ is higher (more negative) than the $\mathrm{Ag}_{2} \mathrm{O}$ valence band. On top of this, the formation of a large number of $\mathrm{Ag}_{2} \mathrm{O}$ clusters can reduce the active sites of the photocatalyst in producing radical species.

\subsection{Antibacterial Test}

From the results of photocatalytic tests on microplastic degradation, we then further expound the virtues of Ag-modified TNT as photocatalysts for disinfection of $E$. coli. Figure 11 displays the profiles of the $E$. coli colony as a function of time for three cases: 1) in the absence of UV illumination and photocatalysts; 2) in the presence of UV illumination and the unmodified TNT; 3) in the presence of UV illumination and $0.03 \mathrm{M} \mathrm{Ag-TNT.} \mathrm{In} \mathrm{the} \mathrm{first} \mathrm{case,}$ there are essentially no bactericidal activities as the $E$. coli colony seems invariant with time, as expected. Under illumination, the unmodified sample (TNT 30V) could reduce the E. coli colony by $97.94 \%$ within 10 minutes and $99.66 \%$ within 60 minutes. Importantly, the $0.03 \mathrm{M}$ Ag-TNT photocatalyst exhibit much better antibacterial properties, as it performs $E$. coli disinfection of up to $99.999 \%$ within 10 minutes under UV-C irradiation. It should be noted that the value of $10 \mathrm{CFU} / \mathrm{mL}$ was used on $0.03 \mathrm{M}$ Ag-TNT profiles to indicate the detection limit (<10 CFU). The bactericidal activity could be rationalized by considering the synergetic effect of UVC illumination and photocatalysis. The UVC spectrum is strongly absorbed by the nucleic acids of a microorganism and, therefore, is lethal for microorganisms. The light-induced damage to the DNA and RNA of a microorganism often results from the dimerization of pyrimidine molecules [56]. Hydroxyl radicals generated during the photocatalytic process further enhanced the microorganism disinfection properties. Other ROS such as atomic oxygen and hydrogen peroxide can also be actively involved in the oxidation of cellular components, membrane leakage of the microbial cell wall, and other processes [57, 58]. Moreover, it is also well documented that $\mathrm{Ag}$ inherently possesses an antimicrobial capacity. Besides playing a role in increasing photocatalytic activities by performing an electron-trapping function to retard electron-hole recombination, $\mathrm{Ag}$ could also react with water to form $\mathrm{Ag}^{+}$and interact with the $\mathrm{SH}$ (retinol) 
group in the bacteria, which eventually kills them [59].

\section{Conclusions}

In this paper, we report the synthesis of $\mathrm{TiO}_{2}$ nanotube arrays that are further modified by either Fe or Ag via a SILAR method to promote photocatalytic activities in degrading microplastics and disinfecting E. Coli. Based on our findings, it is suggested that $\mathrm{Fe}^{3+}$ is more easily incorporated into $\mathrm{TiO}_{2}$ lattice than $\mathrm{Ag}^{+}$; the latter tends to scatter around the surface of $\mathrm{TiO}_{2}$. The addition of $\mathrm{Fe}^{3+}$ into $\mathrm{TiO}_{2}$ nanotubes is apparently detrimental to the photocatalytic degradation of microplastics, as it causes the decrease of microplastic degradation from $17 \%$ in the use of unmodified TNT to $6 \%-9 \%$ in the case of Fe-modified samples. This is presumably because the concentrations are too high for $\mathrm{Fe}^{3+}$ to act as an electron trapper and rather become a recombination center. In contrast, modification by $\mathrm{Ag}$ is evidently beneficial for the removal of microplastics with delicate adjustment on the loading content. A suitable concentration of $\mathrm{Ag}$ (prepared in $0.03 \mathrm{M}$ of precursor solution) added to $\mathrm{TiO}_{2}$ nanotubes may induce a Schottky barrier that is essential for effective separation of the photo-charge carriers, while an excessive amount $(0.06-0.09 \mathrm{M})$ would create clusters of $\mathrm{Ag}$ and $\mathrm{Ag}_{2} \mathrm{O}$ particles that block the photon absorption by photoactive $\mathrm{TiO}_{2}$. In terms of disinfection of $E$. coli, the Ag-modified $\mathrm{TiO}_{2}$ nanotube sample exhibit exceptional bactericidal properties, by killing $99.999 \%$ of the $E$. coli colony in 10 mins. This research is expected to pave the way for further development in maintaining water quality from microplastic contaminants and bacteria via a sustainable process route.

\section{Acknowledgment}

We would like to express our gratitude to Ristek-Dikti for financially supporting this research via the PDUPT grant scheme (Contract no. NKB-2864 / UN2.RST / HKP.05.00 / 2020).

\section{References}

[1] Kosuth, M., Mason, S.A., Wattenberg, E.V. (2018). Anthropogenic contamination of tap water, beer, and sea salt. PloS one, 13(4), e0194970. DOI:10.1371/journal.pone.0194970

[2] Mason, S.A., Welch, V.G., Neratko, J. (2018). Synthetic polymer contamination in bottled water. Frontiers in Chemistry, 6, 407. DOI: 10.3389/fchem.2018.00407
[3] Pinson, A., Franssen, D., Gerard, A., Parent, A.S., Bourguignon, J.P. (2017), Neuroendocrine disruption without direct endocrine mode of action: polychloro-biphenyls (PCBs) and bisphenol A (BPA) as case studies. Comptes Rendus Biologies, 340(9-10), 432438. DOI: $10.1016 /$ j.crvi.2017.07.006

[4] Uheida, A., Mejia, H.G., Abdel-Rehim, M., Hamd, W., Dutta, J. (2021). Visible light photocatalytic degradation of polypropylene microplastics in a continuous water flow system. Journal of Hazardous Materials, 406, 124299. DOI: 10.1016/j.jhazmat.2020.124299

[5] Karim, A.V., Hassani, A., Eghbali, P., Nidheesh, P.V. (2022). Nanostructured modified layered double hydroxides (LDHs)-based catalysts: A review on synthesis, characterization, and applications in water remediation by advanced oxidation processes. Current Opinion in Solid State and Materials Science, $26(1), \quad 100965$. D O I : 10.1016/j.cossms.2021.100965

[6] Wang, Z., Lin, T., Chen, W. (2020). Occurrence and removal of microplastics in an advanced drinking water treatment plant (ADWTP). Science of the Total Environment,

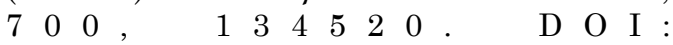
10.1016/j.scitotenv.2019.134520

[7] Hassani, A., Krishnan, S., Scaria, J., Eghbali, P., Nidheesh, P.V. (2021). Z-scheme photocatalysts for visible-light-driven pollutants degradation: A review on recent advancements. Current Opinion in Solid State and Materials Science, 25(5), 100941. DOI: 10.1016/j.cossms.2021.100941

[8] Hassani, A., Faraji, M., Eghbali, P. (2020). Facile fabrication of mpg- $\mathrm{C}_{3} \mathrm{~N}_{4} / \mathrm{Ag} / \mathrm{ZnO}$ nanowires/Zn photocatalyst plates for photodegradation of dye pollutant. Journal of Photochemistry and Photobiology A: Chemistry,

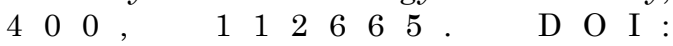
10.1016/j.jphotochem.2020.112665

[9] Motlagh, P.Y., Khataee, A., Hassani, A., and Rad, T.S. (2020). ZnFe-LDH/GO nanocomposite coated on the glass support as a highly efficient catalyst for visible light photodegradation of an emerging pollutant. Journal of Molecular Liquids, 302, 112532. DOI: 10.1016/j.molliq.2020.112532

[10] Moma, J., Baloyi, J. (2018). Modified titanium dioxide for photocatalytic applications. In Sher Bahadar Khan and Kalsoom Akhtar (Editor) Photocatalysts - Applications and Attributes. Croatia: InTech Publisher. DOI: 10.5772/intechopen.79374 
[11] Ariza-Tarazona, M.C., Villareal-Chiu, J.F., Barbieri, V., Siligardi, C., Cedillo-Gonzalez, E.I. (2019). New strategy for microplastic degradation: Green photocatalysis using a protein-based porous $\mathrm{N}-\mathrm{TiO}_{2}$ semiconductor. $\mathrm{Ce}$ ramics International, 45(7), 9618-9624. DOI: 10.1016/j.ceramint.2018.10.208.

[12] Haris, M., Didit, A. Ibadurrohman, M., Setiadi, S., and Slamet, S. (2021). Silver Doped $\mathrm{TiO}_{2}$ Photocatalyst for Disinfection of E. coli and Microplastic Pollutant Degradation in Water. Asian Journal of Chemistry, $33(9), \quad 2038-2042$. D O I : 10.14233/ajchem.2021.23255

[13] Maulana, D.A., Ibadurrohman, M., Slamet, S. (2021). Synthesis of Nano-Composite $\mathrm{Ag} / \mathrm{TiO}_{2}$ for Polyethylene Microplastic Degradation Applications. IOP Conference Series: Materials Science and Engineering, 1011, 012054. DOI: 10.1088/1757-899X/1011/1/012054

[14] Fadli, M.H., Ibadurrohman, M., Slamet, S. (2021). Microplastic Pollutant Degradation in Water Using Modified $\mathrm{TiO}_{2}$ Photocatalyst Under UV-Irradiation. IOP Conference Series: Materials Science and Engineering, 1011, 012055 . D O I : $10.1088 / 1757$ 899X/1011/1/012055

[15] Prakasam, H.E., Shankar, K., Paulose, M., Varghese, O.K., and Grimes, C.A. (2007). A new benchmark for $\mathrm{TiO}_{2}$ nanotube array growth by anodization. The Journal of Physical Chemistry $C, 111(20), 7235-7241$. DOI: 10.1021/jp070273h

[16] Ali, S.S., Qazi, I.A., Arshad, M., Khan, Z., Voice, T.C., and Mehmood, C.T. (2016). Photocatalytic degradation of low density polyethylene (LDPE) films using titania nanotubes. Environmental Nanotechnology, Monitoring \& Management, 5, 44-53. DOI: 10.1016/j.enmm.2016.01.001

[17] Dwirekso, I.H., Ibadurrohman, M., Slamet, S. (2020). Synthesis of $\mathrm{TiO}_{2}-\mathrm{SiO}_{2}-\mathrm{CuO}$ Nanocomposite Material and Its Activities for Selfcleaning. Evergreen, 7(2), 285-291. DOI: $10.5109 / 4055234$

[18] Ibadurrohman, M., Hellgardt, K. (2020). Importance of surface roughness of $\mathrm{TiO}_{2}$ photoanodes in promoting photoelectrochemical activities with and without sacrificial agent. Thin Solid Films, 705, 138009. DOI: 10.1016/j.tsf.2020.138009

[19] Zaleska, A. (2008). Doped- $\mathrm{TiO}_{2}$ : a review. $R e$ cent patents on engineering, 2(3), 157-164. DOI: $10.2174 / 187221208786306289$

[20] Zhang, Y., Shen, Y., Gu, F., Wu, M., Xie, Y., and Zhang, J. (2009). Influence of $\mathrm{Fe}$ ions in characteristics and optical properties of mesoporous titanium oxide thin films. Applied Surface Science, 256(1), 85-89. DOI: 10.1016/j.apsusc.2009.07.074
[21] Nasralla, N.H.S., Yeganeh, M., Astuti, Y., Piticharoenphun, S., Siller, L. (2018). Systematic study of electronic properties of Fe-doped $\mathrm{TiO}_{2}$ nanoparticles by X-ray photoemission spectroscopy. Journal of Materials Science:Materials in Electronics, 29(20), 1795617966. DOI: $10.1007 / \mathrm{s} 10854-018-9911-5$

[22] Nasralla, N., Yeganeh, M., Astuti, Y., Piticharoenphun, Shahtahmasebi, N., Kompany, A., Karimipour, M., Mendis, B.G., Poolton, N.R.J., Siller, L. (2013). Structural and spectroscopic study of Fe-doped $\mathrm{TiO}_{2}$ nanoparticles prepared by sol-gel method. Scientia Iranica, 20(3), 1018-1022. DOI: 10.1016/j.scient.2013.05.017

[23] Syrek, K., Grudzien, J., Sennik-Kubiec, A., Brudzisz, A., Sulka, G.D. (2019). Anodic Titanium Oxide Layers Modified with Gold, Silver, and Copper Nanoparticles. Journal of Nanomaterials, 2019, 9208734. DOI: $10.1155 / 2019 / 9208734$

[24] Yue, X., Manach, A., Dong, J., Gao, W. (2019). Preparation of Ag-decorated $\mathrm{TiO}_{2}$ nanotube electrode and its catalytic property. International Journal of Modern Physics B, 33, 1940023. DOI: 10.1142/S021797921940023X

[25] Momeni, M.M., Ghayeb, Y., Mozafari, A.A. (2016). Optical and photo catalytic characteristics of $\mathrm{Ag}_{2} \mathrm{~S} / \mathrm{TiO}_{2}$ nanocomposite films prepared by electrochemical anodizing and SILAR approach. Journal of Materials Science: Materials in Electronics, 27(11), 11201-11210. DOI: $10.1007 / \mathrm{s} 10854-016-5240-8$

[26] Wang, X., Zhao, J., Li, Z., Yin, Z., Wu, Z., and Wang, X. (2021), Facile SILAR preparation of $\mathrm{Fe}(\mathrm{OH})_{3} / \mathrm{Ag} / \mathrm{TiO}_{2}$ nanotube arrays ternary hybrid for supercapacitor negative electrode. International Journal of Hydrogen Energy, $46(12), \quad 8702-8721$. D O I : 10.1016/j.ijhydene.2020.12.048

[27] Venturini, J., Bonatto, F., Guaglianoni, W.C., Lemes, T., Arcaro, S., Alves, A.K., and Bergmann, C.P. (2019). Cobalt-doped titanium oxide nanotubes grown via one-step anodization for water splitting applications. $A p$ plied Surface Science, 464, 351-359. DOI: 10.1016/j.apsusc.2018.09.093

[28] Junkar, I., Kulkarni, M., Bencina, M, Kovac, J., Mrak-Polsak, K., Lakota, K., Sodin-Semrl, S., Mozetic, M., Iglic, A. (2020). Titanium dioxide nanotube arrays for cardiovascular stent applications. ACS omega, 5(13), 72807289. DOI: 10.1021 /acsomega.9b04118

[29] Durdu, S., Cihan, G., Yalcin, E., Altinkok, A. (2021). Characterization and mechanical properties of $\mathrm{TiO}_{2}$ nanotubes formed on titanium by anodic oxidation. Ceramics International, 47(8), 10972-10979. DOI: 10.1016/j.ceramint.2020.12.218 
[30] Peng, Z., Ni, J. (2019). Surface properties and bioactivity of $\mathrm{TiO}_{2}$ nanotube array prepared by two-step anodic oxidation for biomedical applications. Royal Society Open Science, 6(4), 181948. DOI: 10.1098/rsos.181948

[31] Sahrin, N.T., Nawaz, R., Chong, F.K., Lee, S.L., Wirzal, M.D.H. (2021). Current perspectives of anodized $\mathrm{TiO}_{2}$ nanotubes towards photodegradation of formaldehyde: A short review. Environmental Technology \& Innovation, $22, \quad 101418$. D O I : 10.1016/j.eti.2021.101418

[32] Lockman, Z., Sreekantan, S., Ismail, S., Schmidt-Mende, L., Macmanus-Driscoll, J.L. (2010). Influence of anodisation voltage on the dimension of titania nanotubes. Journal of $\mathrm{Al}$ loys and Compounds, 503(2), 359-364. DOI: 10.1016/j.jallcom.2009.12.093

[33] Lai, C.W., Sreekantan, S. (2011). Effect of applied potential on the formation of selforganized $\mathrm{TiO}_{2}$ nanotube arrays and its photoelectrochemical response. Molecules, 14, 1618. DOI: $10.1155 / 2011 / 142463$

[34] Prakash, J., Sun, S., Swart, H.C., Gupta, R.K. (2018). Noble metals- $\mathrm{TiO}_{2}$ nanocomposites: from fundamental mechanisms to photocatalysis, surface enhanced Raman scattering and antibacterial applications. Applied Materials Today, $11, \quad 82-135$. D O I : 10.1016/j.apmt.2018.02.002

[35] Lakkim, V., Reddy, M.C., Pallavali, R.R., Reddy, K.R., Reddy, C.V., Inamuddin, I., Bilgrami, A.L., Lomada, D. (2020). Green synthesis of silver nanoparticles and evaluation of their antibacterial activity against multidrug-resistant bacteria and wound healing efficacy using a murine model. Antibiotics, 9(12), 902. DOI: 10.3390/antibiotics9120902

[36] Singh, Y., Kaushal, S., Sodhi, R.S. (2020). Biogenic synthesis of silver nanoparticles using cyanobacterium Leptolyngbya sp. WUC 59 cell-free extract and their effects on bacterial growth and seed germination. Nanoscale Advances, 2(9), 3972-3982. DOI: 10.1039/D0NA00357C

[37] Sabir, A., Sherazi, T.A., Xu, Q. (2021). Porous polymer supported $\mathrm{Ag}-\mathrm{TiO}_{2}$ as green photocatalyst for degradation of methyl orange. Surfaces and Interfaces, 26, 101318. DOI: 10.1016/j.surfin.2021.101318

[38] Ghanbari, F., Hassani, A., Waclawek, S., Wang, Z., Matyszczak, G., Lin, K.A., and Dolatabadi, M. (2021). Insights into paracetamol degradation in aqueous solutions by ultrasound-assisted heterogeneous electroFenton process: Key operating parameters, mineralization and toxicity assessment. Separation and Purification Technology, 266, 118533. DOI: 10.1016/j.seppur.2021.118533
[39] Eghbali, P., Hassani, A., Sundu, B., Metin, O. (2019). Strontium titanate nanocubes assembled on mesoporous graphitic carbon nitride $\left(\mathrm{SrTiO}_{3} / \mathrm{mpg}-\mathrm{C}_{3} \mathrm{~N}_{4}\right)$ : Preparation, characterization and catalytic performance. Journal of Molecular Liquids, 290, 111208. DOI: 10.1016/j.molliq.2019.111208

[40] Liang, W., Luo, Y., Song, S., Dong, X., Yu, X. (2013). High photocatalytic degradation activity of polyethylene containing polyacrylamide grafted $\mathrm{TiO}_{2}$. Polymer Degradation and Stability, 98(9), 1754-1761. DOI: 10.1016/j.polymdegradstab.2013.05.027

[41] Zhao, X.U., Li, Z., Chen, Y., Shi, L., Zhu, Y. (2007). Solid-phase photocatalytic degradation of polyethylene plastic under UV and solar light irradiation. Journal of Molecular Catalysis A: Chemical, 268(1), 101-106. DOI: 10.1016/j.molcata.2006.12.012

[42] Zan, L., Tian, L., Liu, Z., Peng, Z. (2004). A new polystyrene- $\mathrm{TiO}_{2}$ nanocomposite film and its photocatalytic degradation. Applied Catalysis A: General, 264(2), 237-242. DOI: 10.1016/j.apcata.2003.12.046

[43] Lei, J., Li, X., Li, W., Sun, F., Lu, D., Lin, Y. (2012). Photocatalytic degradation of methyl orange on arrayed porous iron-doped anatase $\mathrm{TiO}_{2}$. Journal of Solid State Electrochemistry, 16(2), 625-632. DOI: 10.1007/s10008-011$1388-6$

[44] Patel, N., Dashora, A., Jaiswal, R., Fernandes, R., Yadav, M., Kothari, D.C., Ahuja, L., Miotello, A. (2015). Experimental and theoretical investigations on the activity and stability of substitutional and interstitial boron in $\mathrm{TiO}_{2}$ photocatalyst. The Journal of Physical Chemistry C, 119(32), 18581-18590. DOI: 10.1021/acs.jpcc.5b05290

[45] Zhu, J., Zheng, W., He, B., Zhang, J., Anpo, M. (2004). Characterization of $\mathrm{Fe}-\mathrm{TiO}_{2}$ photocatalysts synthesized by hydrothermal method and their photocatalytic reactivity for photodegradation of XRG dye diluted in water. Journal of Molecular Catalysis A: Chemical. $216(1), \quad 35-43 . \quad$ D O I : 10.1016/j.molcata.2004.01.008

[46] Fan, X., Fan, J., Hu, X., Liu, E., Kang, L., Tang, C., Ma, Y., Wu, H., Li Y. (2014). Preparation and characterization of $\mathrm{Ag}$ deposited and $\mathrm{Fe}$ doped $\mathrm{TiO}_{2}$ nanotube arrays for photocatalytic hydrogen production by water splitting. Ceramics International, 40(10), 1590715917. DOI: 10.1016/j.ceramint.2014.07.119

[47] Sood, S., Umar, A., Mehta, S.K., Kansal, S.K. (2015). Highly effective Fe-doped $\mathrm{TiO}_{2}$ nanoparticles photocatalysts for visible-light driven photocatalytic degradation of toxic organic compounds. Journal of Colloid and Interface Science, 450, 213-223. DOI: 10.1016/j.jcis.2015.03.018 
[48] Zhu, J., Chen, F., Zhang, J., Chen, H., Anpo, M. (2006). $\mathrm{Fe}^{3+}-\mathrm{TiO}_{2}$ photocatalysts prepared by combining sol-gel method with hydrothermal treatment and their characterization. Journal of Photochemistry and Photobiology A: Chemistry, 180(1-2), 196-204. DOI: 10.1016/j.jphotochem.2005.10.017

[49] Momeni, M.M., Ghayeb, Y. (2015). Fabrication, characterization and photoelectrochemical behavior of $\mathrm{Fe}-\mathrm{TiO}_{2}$ nanotubes composite photoanodes for solar water splitting. Journal of Electroanalytical Chemistry, 751, 43-48. DOI: 10.1016/j.jelechem.2015.05.035

[50] Guaglianoni, W.C., Ruwer, T.L., Caldeira, L.E.N., Wermuth, T.B., Venturini, J., Bergmann, C.P. (2021). Single-step synthesis of $\mathrm{Fe}-\mathrm{TiO}_{2}$ nanotube arrays with improved light harvesting properties for application as photoactive electrodes. Materials Science and Engineering: $B, \quad 263, \quad 114896 . \quad$ DOI: 10.1016/j.mseb.2020.114896

[51] Khan, M.R., Chuan, T.W., Yousuf, A., Chowdhury, M.N.K., Cheng, C.K. (2015). Schottky barrier and surface plasmonic resonance phenomena towards the photocatalytic reaction: study of their mechanisms to enhance photocatalytic activity. Catalysis Science \& Technology, 5(5), 2522-2531. DOI: 10.1039/C4CY01545B

[52] Xue, X., Gong, X., Chen, X., Chen, B.Y. (2021). A facile synthesis of $\mathrm{Ag} / \mathrm{Ag}_{2} \mathrm{O} @ \mathrm{TiO}_{2}$ for toluene degradation under UV-visible light: Effect of $\mathrm{Ag}$ formation by partial reduction of $\mathrm{Ag}_{2} \mathrm{O}$ on photocatalyst stability. Journal of Physics and Chemistry of Solids, 150, 109799. DOI: 10.1016/j.jpcs.2020.109799

[53] Akel, S., Dillert, R., Balayeva, N.O., Boughaled, R., Koch, J., El-Azzouzi, M., and Bahnemann, D.W. (2018). $\mathrm{Ag} / \mathrm{Ag}_{2} \mathrm{O}$ as a cocatalyst in $\mathrm{TiO}_{2}$ photocatalysis: effect of the co-catalyst/photocatalyst mass ratio. Catalysts, 8(12), 647. DOI: 10.3390/catal8120647
[54] Liu, B., Mu, L., Han, B., Zhang, J., Shi, H. (2017). Fabrication of $\mathrm{TiO}_{2} / \mathrm{Ag}_{2} \mathrm{O}$ heterostructure with enhanced photocatalytic and antibacterial activities under visible light irradiation. Applied Surface Science, 396, 1596-1603. DOI: 10.1016/j.apsusc.2016.11.220

[55] Ding, W., Zhao, L., Yan, H., Wang, X., Liu, X., Zhang, X., Huang, X., Hang, R., Wang, Y., Yao, X., Tang, B. (2019). Bovine serum albumin assisted synthesis of $\mathrm{Ag} / \mathrm{Ag}_{2} \mathrm{O} / \mathrm{ZnO}$ photocatalyst with enhanced photocatalytic activity under visible light. Colloids and Surfaces A: Physicochemical and Engineering Aspects, $568, \quad 131-140 . \quad$ D O I : 10.1016/j.colsurfa.2019.02.015

[56] Dai, T., Vrahas, M.S., Murray, C.K., Hamblin, M.R. (2012). Ultraviolet C irradiation: an alternative antimicrobial approach to localized infections?. Expert Review of AntiInfective Therapy, 10(2), 185-195. DOI: 10.1586/eri.11.166

[57] Cabiscol C.E., Sumalla, J.T., Salvador, J.R. (2000). Oxidative stress in bacteria and protein damage by reactive oxygen species. International Microbiology, 3(1), 3-8. DOI: 10.2436/IM.V3I1.9235

[58] Reddy, P.A.K., Reddy, P.V.L., Kwon, E., Kim, K.H., Akter, T., Kalagara, S. (2016). Recent advances in photocatalytic treatment of pollutants in aqueous media. Environment International, 91, 94-103. DO I : 10.1016/j.envint.2016.02.012

[59] Sunada, K., Watanabe, T., Hashimoto, K. (2003). Bactericidal activity of copperdeposited $\mathrm{TiO}_{2}$ thin film under weak UV light illumination. Environmental Science \& Technology, 37(20), 4785-4789. DOI: $10.1021 / \mathrm{es} 034106 \mathrm{~g}$ 